\title{
Eosinophilic fasciitis and the carpal tunnel syndrome
}

\author{
H ROYDEN JONES, JR,* WILLIAM P BEETHAM, JR, $\dagger$ MARK L SILVERMAN, \\ STEVEN W MARGLES§
}

From the Department of Neurology, ${ }^{*}$ Section of Rheumatology, $\dagger$ Department of Pathology, $\ddagger$ and Department of Orthopaedic Surgery, $\S$ Lahey Clinic Medical Center, Burlington, MA, USA

SUMMARY Eosinophilic fasciitis is characterised by induration and inflammation of the fascia of the extremities. It is a nosologically distinct clinical entity typified by swelling, tenderness, and stiffness of the extremities associated with peripheral eosinophilia. Six of our eight patients with eosinophilic fasciitis seen in a $3 \frac{1}{2}$ year period have had an associated carpal tunnel syndrome. The presenting complaints in three patients were those of carpal tunnel syndrome and in the other three patients were muscle aching, swelling, and tightness. Diagnosis was made by EMG and deep fascial biopsy. Although small doses of corticosteroid medications were helpful initially in five of the six patients, two patients later required surgical decompression.

Eosinophilic fasciitis, originally described by Shulman ${ }^{1}$ in 1974, is characterised by inflammation and sclerosis of deep subcutaneous fascia and collagen bundles involving the extremities. Clincally, patients with eosinophilic fasciitis have a distinct appearance that some physicians have likened to that of scleroderma. However, careful review usually demonstrates clinical features that help distinguish this illness from the other diseases of connective tissue. In some patients the onset of eosinophilic fasciitis may be acute, sometimes following exercise, but in others an insidious, progressive, or remitting and relapsing course may occur. Patients complain of symmetric swelling, tenderness, and stiffness of an extremity, maximally involving the lower forearm and less often the leg but usually sparing hands and feet. Careful palpation often demonstrates a characteristic thickening and induration of the soft tissues. The skin may have a puckered appearance like that of an orange peel (fig 1). An absolute eosinophilia is usually present in the peripheral blood. ${ }^{2}$

Presented at the 30th Annual Meeting of the American Association of Electromyography and Electrodiagnosis, Toronto, Ontario, Canada, September 30-October 1, 1983.

Address for reprint requests: Dr H Royden Jones, Jr, Department of Neurology, Lahey Clinic Medical Center, 41 Mall Road, Burlington, MA 01805, USA.

Received 19 February 1985 and in revised form 17 June 1985. Accepted 24 June 1985
Earlier reports ${ }^{2-5}$ have mentioned the presence of an associated carpal tunnel syndrome in about or $N$ third of patients. This was common in our experience. 을 and we believe that it is important to emphasise this to other neurologists as carpal tunnel syndrome may be the first symptom of eosinophilic fasciitis.

Between January 1980 and June 1983 we saw eig patients with eosinophilic fasciitis. Each chart ha्s. $\overrightarrow{0}$ been reviewed, and six patients met the commonly accepted clinical and electrodiagnostic criteria for carpal tunnel syndrome.

Case reports

Illustrative case report

A 40-year-old man, a business executive, presented with a $\overrightarrow{\bar{O}}$

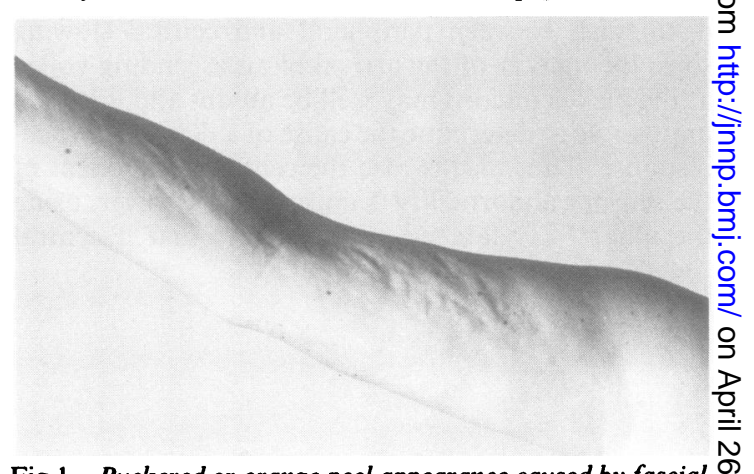

Fig 1 Puckered or orange peel appearance caused by fascial induration and inflammation. 
three month history of nocturnal numbness, tingling, and burning of the second to fourth digits of the left hand, sometimes spreading into the forearm. Similar symptoms had occurred in the right hand, on occasion precipitated by driving or talking on the telephone. The severity of the rightsided symptoms had lessened since their onset one year earlier. Initially the patient noted stiffness of the hands and elbows, particularly in the morning, and of the hips and knees after prolonged sitting.

Abnormal findings on physical examination included positive Tinel and Phalen signs on the left side and subjective diminution in sensation of the left median nerve associated with mild tightness of the skin of the fingers, firm induration of the forearm, and modest limitation of wrist flexion and extension. Abnormal laboratory findings included a peripheral eosinophil count of $9.5 \%$ with a total leukocyte count of $7000 / \mathrm{mm}^{3}$ and serum SGOT of $52 \mathrm{IU} / 1$ (normal $11-40 \mathrm{IU} / \mathrm{l}$ ). Other pertinent laboratory data included serum creatine kinase of $17 \mathrm{IU} / 1$ (normal 10-110 IU/l), an erythrocyte sedimentation rate (Westergren method) of $3 \mathrm{~mm} / \mathrm{hr}$, and negative findings of latex fixation and antinuclear antibody studies. Deep fascial biopsy demonstrated eosinophilic fasciitis. Prednisone, $20 \mathrm{mg} / \mathrm{d}$, produced improvement of the carpal tunnel syndrome symptoms within 30 days, but the symptoms returned when the dose was decreased to $2.5 \mathrm{mg} / \mathrm{d}$. The patient was returned to a dose of $10 \mathrm{mg} / \mathrm{d}$ for a few weeks and again reached resolution of symptoms. Symptoms did not recur when prednisone was stopped six months after the initial evaluation.

\section{Clinical features}

Our six patients were aged $30,31,33,40,44$, and 52 years. Three were men and three were women. Symptoms of carpal tunnel syndrome, that is, numbness and tingling particularly of the hands with nocturnal awakening, were present in all six patients and were the initial complaints in three. Symptoms of carpal tunnel syndrome were present bilaterally in four of these six patients and fluctuated greatly in two of the six. Two patients complained of aching of muscles and soft tissues. Other symptoms included fatigue in three patients, swelling and tenderness of the skin in two patients, and stiffness of the neck in one patient. Exercise was a precipitating mechanism in only one of our patients. On physical examination all patients had induration, tightness, and puckering of the skin of the arm, and in some this was present on the neck and thigh. Neurologic examination demonstrated minimal sensory changes in four of five patients, all in the median nerve distribution. One patient had slight thenar weakness. The Tinel sign was positive in all five patients in whom it was checked. The Phalen sign was positive in one patient and was not tested in the remaining five patients, in one because of stiffness and fibrosis.

\section{Laboratory data}

All patients had evidence of a peripheral eosinophilia that ranged from $6 \%$ to $27 \%$ of the white blood count. On multiple testing, every patient had a count of at least $9 \%$. Two patients had absolute eosinophil counts performed with results of 840 and $880 / \mathrm{mm}^{3}$, respectively (normal $100-300 / \mathrm{mm}^{3}$ ). Modest elevations of the erythrocyte sedimentation rate ranging from $35-55 \mathrm{~mm} / \mathrm{h}$ were noted in two patients, whereas four patients had values between 5 and
$14 \mathrm{~mm} / \mathrm{h}$. Other authors ${ }^{16}$ have mentioned the presence of an increased serum gamma globulin fraction. However, all five of our patients having serum protein profiles had normal values. The antinuclear antigen titres and latex values were normal in each of the three patients examined. Serum level of SGOT was minimally increased at $52 \mathrm{IU} / \mathrm{l}$ in one of our patients, and in another patient creatine kinase was slightly elevated at $119 \mathrm{IU} / 1$.

\section{Electrodiagnostic studies}

Nerve conduction and EMG studies were performed in five of the six patients with one patient declining these studies but having classic symptoms of carpal tunnel syndrome and biopsy-proved eosinophilic fasciitis. Findings in four patients (table) demonstrated change in sensory latency of median nerve to be the most sensitive indicator. Motor and sensory studies of ulnar nerve showed normal values in a maximally affected extremity in the four patients. One patient had studies performed elsewhere and was reported to have mild prolongations of distal latencies of median nerve.

\section{Pathology}

In each patient deep fascial biopsy was performed and was diagnostic. The findings are typical and similar to those in other reported cases of eosinophilic fasciitis. ${ }^{6}$ The epidermis and dermis usually appear relatively normal. The subcutaneous fascia is often thickened to two to three times normal, with focal nodular accentuations measuring up to eight times normal thickness (fig 2). Infiltrates of lymphocytes, plasma cells, histiocytes, and rare eosinophils located within dense and organising fibrous tissue are characteristic. Focal distribution of eosinophils has often been found but does not need to be present for diagnosis. No appreciable necrosis of adjacent fat tissue. is seen, but inflammatory cells may occur in connective tissue septa extending into fatty tissue. Examination of the attached muscle may reveal focal perivascular lymphocyte aggregates and inflammatory cells in septa separating muscular tissue. No appreciable degree of myositis or degenerative muscle change was found in five of the six patients. A mild focal myositis was seen in one patient.

\section{Therapy and course}

Each patient was treated with a low dose of prednisone, $10-20 \mathrm{mg} / \mathrm{d}$, associated with the use of wrist splints. One patient had previously experienced spontaneous clearing of symptoms without therapy, but the opposite wrist became involved and required therapy. Five of the six patients had a good response to therapy. However, in addition to the one patient not helped initially by corticocosteroids, two others had a recurrence of symptoms when the dose was decreased. Two patients have required tenosynovectomy with surgical decompression of the flexor tendons. Their response to operation has been good. Direct corticosteroid injection was utilised only once as a temporising measure in a patient who had acute worsening of symptoms of carpal tunnel syndrome and required operation two weeks later.

\section{Discussion}

The physician seeing a patient with carpal tunnel syndrome should always consider the possibility of 
Table Results of median nerve conduction and EMG studies in patients with carpal tunnel syndrome and eosinophilic fasciitis

\begin{tabular}{|c|c|c|c|c|c|c|c|c|}
\hline \multirow[t]{2}{*}{ Patient } & \multirow{2}{*}{$\begin{array}{l}\text { Sex, } \\
\text { age }(y r)\end{array}$} & \multirow[t]{2}{*}{ Side } & \multicolumn{3}{|l|}{ Motor } & \multicolumn{2}{|l|}{ Sensory } & \multirow[t]{2}{*}{$E M G$} \\
\hline & & & $\begin{array}{l}\text { Compound } \\
\text { action } \\
\text { potential } \\
(4-18 \mathrm{mV})\end{array}$ & $\begin{array}{l}\text { Conduction } \\
\text { velocity } \\
(49-70 \mathrm{~m} / \mathrm{s})\end{array}$ & $\begin{array}{l}\text { Distal } \\
\text { latency } \\
(2 \cdot 4-4 \cdot 4 \mathrm{~ms})\end{array}$ & $\begin{array}{l}\text { Compound } \\
\text { action } \\
\text { potential } \\
(15-50 \mu \mathrm{V})\end{array}$ & $\begin{array}{l}\text { Distal } \\
\text { latency } \\
(2 \cdot 5-3.5 \mathrm{~ms})\end{array}$ & \\
\hline 1 & M 40 & $\begin{array}{l}\text { Left } \\
\text { Right }\end{array}$ & $\begin{array}{l}5 \\
6\end{array}$ & $\begin{array}{l}54 \\
53\end{array}$ & $\begin{array}{l}4 \cdot 2 \\
3 \cdot 2\end{array}$ & $\begin{array}{l}15 \\
20\end{array}$ & $\begin{array}{l}5.43^{*} \\
3.91^{*}\end{array}$ & Normal \\
\hline 2 & F 44 & $\begin{array}{l}\text { Left } \\
\text { Right }\end{array}$ & $\begin{array}{l}2 \cdot 5^{*} \\
2 \cdot 0^{*}\end{array}$ & $\begin{array}{l}59 \\
46\end{array}$ & $\begin{array}{l}4 \cdot 6^{*} \\
4 \cdot 8^{*}\end{array}$ & $\begin{array}{l}4 \cdot 0^{*} \\
4 \cdot 0^{*}\end{array}$ & $\begin{array}{l}4 \cdot 80^{*} \\
4 \cdot 40^{*}\end{array}$ & Normal \\
\hline 3 & F 33 & $\begin{array}{l}\text { Left } \\
\text { Right }\end{array}$ & $\begin{array}{l}\text { NP } \\
6\end{array}$ & $\begin{array}{l}\text { NP } \\
62\end{array}$ & $\begin{array}{l}\text { NP } \\
4 \cdot 0\end{array}$ & 20 & $\begin{array}{l}2 \cdot 9 \\
4 \cdot 4^{*}\end{array}$ & Normal \\
\hline 4 & M 52 & $\begin{array}{l}\text { Left } \\
\text { Right }\end{array}$ & NP & $\begin{array}{l}70 \\
\text { NP }\end{array}$ & $\begin{array}{l}5 \cdot 0^{*} \\
\text { NP }\end{array}$ & $\begin{array}{l}15 \\
12^{*}\end{array}$ & $\begin{array}{l}3 \cdot 7^{*} \\
3 \cdot 3\end{array}$ & $\begin{array}{l}\text { Chronic } \\
\text { denervation }\end{array}$ \\
\hline
\end{tabular}

(Normal range)

NP $=$ Not performed

*Abnormal

eosinophilic fasciitis in the differential diagnosis, particularly because symptoms of carpal tunnel syndrome may be the presenting ones in patients with eosinophilic fasciitis. In each of our patients the median nerve alone was involved clinically or on electrodiagnostic studies. There appears to be no relationship to the idiopathic hypereosinophilic syndrome, which is sometimes associated with multiple mononeuropathy. ${ }^{7}$ None of our patients had evidence of infection, neoplasm, or vasculitis known to be associated with hypereosinophilia. Although each of our patients had at least one elevated eosinophil count of $9 \%$ or above, such is not necessary for a diagnosis as five of 14 patients in one series ${ }^{2}$ had normal counts.

The underlying pathophysiologic mechanism of carpal tunnel syndrome appears to be a compressive phenomenon secondary to inflammatory involvement of the tenosynovium of the flexor tendons compressing the median nerve in the limited space of the

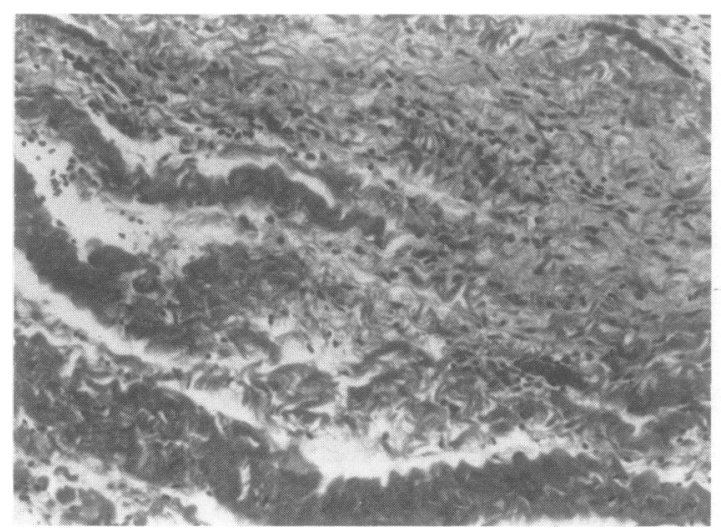

Fig 2 The subcutaneous fascia appears greatly thickened and exhibits waxy collagenous bundles typical of eosinophilic fasciitis (haematoxylin-eosin, $\times$ 400). carpal canal at the wrist. Diagnosis is dependent on pathologic confirmation. ${ }^{18-11}$ Of utmost importance in the pathologic evaluation of these patients is biopsy from the region of maximal induration noted on clinical examination. Care should be taken to obtain an intact full-thickness block of tissue, including skin, subcutaneous tissue, and adjacent muscle. Fascial planes are preserved with this type of biopsy.

Clinically and pathologically the chief differentiaf diagnosis with eosinophilic fasciitis is scleroderma Scleroderma most often involves the dermis, whic becomes thickened with coarse collagen bundles tha@ may replace subcutaneous fat. Atrophy of the epider mis and loss of accessory skin structures may occuro In eosinophilic fasciitis, the relative sparing of the dermis, with greater concentration of disease in the subcutaneous fascial planes, is helpful in diagnosis Raynaud's phenomenon is common in systemic scleroderma but is unusual in eosinophilic fasciitis. ${ }^{2}$ Only one of our six patients had typical Raynaud's phenomenon. Furthermore, the well-known systemic manifestations of scleroderma, that is, involvement of heart, lung, kidney, and esophagus, do not develop in patients with eosinophilic fasciitis.

Although occasional patients may have spontaneous resolution of symptoms, most patients require medical therapy. A corticosteroid dose of $10-30 \mathrm{mg}$ of prednisone per day is usually necessary and is often effective for both the eosinophilic fasciitis and the associated carpal tunnel syndrome. Surgical therapy may eventually be required for the carpal tunnel syndrome symptoms in an appreciable percentage of patients, as two of our six patients with carpal tunnel syndrome and three of four mentioned by Michet et $a l^{2}$ later needed surgical decompression.

\section{References}

${ }^{1}$ Shulman LE. Diffuse fasciitis with hypergammaglobulinemia and eosinophilia: a new syndrome? 
J Rheumatol 1974;1(Suppl 1):46 (abstract).

${ }^{2}$ Michet CJ Jr, Doyle JA, Ginsburg WW. Eosinophilic fasciitis: report of 15 cases. Mayo Clin Proc 1981;56:27-34.

${ }^{3}$ Moore TL, Zuckner J. Eosinophilic fasciitis. Semin Arthritis Rheum 1981;9:228-35.

${ }^{4}$ Rodrigues J, Patten BM. Eosinophilic fasciitis: report of three cases. Neurology (Minneap) 1978;28:400 (abstract).

${ }^{5}$ Wollheim FA, Lindstrom CG, Eiken O. Eosinophilic fasciitis complicated by carpal tunnel syndrome. $J$ Rheumatol 1981;8:856-60.

${ }^{6}$ Moutsopoulos HM, Webber BL, Pavlidis NA, et al. Diffuse fasciitis with eosinophilia: a clinicopathologic study. Am J Med 1980;68:701-9.

${ }^{7}$ Dorfman LJ, Ransom BR, Formo LS, et al. Neuropathy in the hypereosinophilic syndrome. Muscle Nerve 1983;6:291-8.

${ }^{8}$ Barnes L, Rodman GP, Medsger TA, et al. Eosinophilic fasciitis: a pathologic study of twenty cases. Am J Pathol 1979;96:493-517.

${ }^{9}$ Cramer SF, Kent L, Abramowsky C, et al. Eosinophilic fasciitis: immunopathology, ultrastructure, literature review, and consideration of its pathogenesis and relation to scleroderma. Arch Pathol Lab Med 1982;106:85-91.

${ }^{10}$ Kent LT, Cramer SF, Moskowitz RW. Eosinophilic fasciitis: clinical, laboratory, and microscopic considerations. Arthritis Rheum 1981;24:677-83.

${ }^{11}$ Weinstein D, Schwartz RA. Eosinophilic fasciitis. Arch Dermatol 1978;114:1047-9. 